\title{
Bundle to care for newborn children of mothers with suspected or confirmed diagnosis of COVID-19
}

\author{
Bundle para atendimento de recém-nascidos filhos de mães com \\ suspeita ou diagnóstico confirmado de COVID-19 \\ Bundle para el cuidado de hijos recién nacidos de madres con \\ sospechado o diagnóstico confirmado por COVID-19
}

\section{Maria Paula Custódio Silva ${ }^{a}$ \\ Nylze Helena Guillarducci Rocha ${ }^{a}$ \\ Cinthia Lorena Silva Barbosa Teixeira ${ }^{a}$ \\ Flávia da Veiga Ued ${ }^{a}$ \\ Mariana Torreglosa Ruiz ${ }^{\mathrm{a}}$ \\ Divanice Contim $^{\mathrm{a}}$}

\begin{abstract}
How to cite this article: Silva MPC, Rocha NHG, Teixeira CLSB, Ued FV, Ruiz MT, Contim D. Bundle to care for newborn children of mothers with suspected or confirmed diagnosis of COVID-19. Rev Gaúcha Enferm. 2021;42(spe):e20200391. doi: https://doi.org/10.1590/19831447.2021.20200391
\end{abstract}

Universidade Federal do Triângulo Mineiro (UFTM) Uberaba, Minas Gerais, Brasil.

\section{ABSTRACT}

Objective: To build and validate the contents of a bundle for the care of newborn children of mothers with suspected or confirmed diagnosis of COVID-19 in the delivery room and in the rooming-in care.

Method: Methodological research, developed in 2020 in three stages: bibliographic survey, construction of the instrument in Google Forms ${ }^{\circledR}$ and content validation by seven judges. The initial instrument consisted of seven nursing care. The content validity index above $80 \%$ was used to assess the agreement between the judges.

Results: All items in the bundle reached agreement among judges above $80 \%$ after the third round of evaluation. The final version consisted of six items.

Conclusion: This study allowed the construction and content validation of the proposed bundle. The content proved to be valid and may contribute to the quality of nursing care in the face of the care of these newborns.

Keywords: Coronavirus infections. Infant, newborn. Nursing.

\section{RESUMO}

Objetivo: Construir e validar o conteúdo de um bundle para atendimento de recém-nascidos filhos de mães com suspeita ou diagnóstico confirmado de COVID-19 na sala de parto e no alojamento conjunto.

Método: Pesquisa metodológica, desenvolvida no ano de 2020, em três etapas: levantamento bibliográfico, construção do instrumento no Google Formulários ${ }^{\circledast}$ e validação de conteúdo por sete juízes. 0 instrumento inicial foi composto por sete cuidados de Enfermagem. 0 Índice de Validade de Conteúdo acima de $80 \%$ foi utilizado para avaliar a concordância entre os juízes.

Resultados: Todos os itens do bundle alcançaram concordância entre os juízes acima de $80 \%$ após a terceira rodada de avaliação. A versão final foi composta por seis itens.

Conclusão: Este estudo permitiu a construção e a validação de conteúdo do bundle proposto. 0 conteúdo demonstrou-se válido e poderá contribuir para a qualidade da assistência de Enfermagem frente ao atendimento desses recém-nascidos.

Palavras-chave: Infecções por coronavírus. Recém-nascido. Enfermagem.

\section{RESUMEN}

Objetivo: Construir y validar el contenido de un bundle para cuidar a los recién nacidos de madres con diagnóstico sospechado o confirmado de COVID-19 en la sala de partos y alojamiento conjunto.

Método: Investigación metodológica, desarrollada en 2020 en tres etapas: levantamiento bibliográfico, construcción del instrumento en Google Forms ${ }^{\circledast}$ y validación de contenido por siete jueces. El instrumento inicial consistió en siete cuidados de enfermería. El índice de validez de contenido superior al 80\% se utilizó para evaluar la concordancia entre los jueces.

Resultados: Todos los elementos del bundle llegaron a un acuerdo entre los jueces por encima del 80\% después de la tercera ronda de evaluación. La versión final constaba de seis ítems.

Conclusión: Este estudio permitió la construcción y validación de contenido del bundle propuesto. El contenido demostró ser válido y puede contribuir a la calidad de la atención de enfermería frente al cuidado de estos recién nacidos. Palabras clave: Infecciones por coronavirus. Recién nacido. Enfermería. 


\section{INTRODUCTION}

The SARS-CoV-2 virus, first identified in late 2019, has been characterized as the agent of the new infectious respiratory syndrome called COVID-19 ${ }^{(1)}$. The virus, isolated for the first time in China, spread quickly and, in March 2020, the World Health Organization (WHO) declared the pandemic from the new Coronavirus ${ }^{(1-2)}$.

he accelerated propagation curve and the high lethality overloaded health systems, depleting supplies and human resources. Among the countries most affected, the following stand out: United States, Brazil, India, Italy, China and Spain ${ }^{(1)}$. Given the magnitude of the disease, researchers around the world are looking for measures for control and treatment of cases.

It is considered suspected or confirmed the person who: has been in contact with an individual with a suspected or confirmed diagnosis, at home or in other environments, even asymptomatic; report measured or reported fever and cough and/or sore throat and/or dyspnea or have a positive SARS-CoV-2 test result in the last 14 days ${ }^{(3)}$.

The newborns should be considered suspicious if they are exposed to family members, health staff or infected visitors, have mother with a suspected or confirmed infection between 14 days before delivery and 28 days after delivery, or if they present lymphocytopenia on the result of the complete blood count and/or typical findings on lung imaging ${ }^{(4)}$.

Information on COVID-19 in the prenatal and postnatal period is limited. The manifestation of the disease in newborns has been described as mild or moderate, however, the immaturity of the immune system of this period can make them more susceptible to the virus. It is known that exposure and prolonged interaction during labor and birth increase the risk of contagion for the mother, the newborn and the health team. Therefore, it is necessary to establish preventive and protective measures for pregnant women and newborns, considered groups at risk for COVID-19 and of priority assistance ${ }^{(3)}$.

In order to provide practical and objective guidance in the care of newborn children of mothers with suspected or confirmed diagnosis for COVID-19, this study proposes to develop a bundle. It consists of a small set of interventions with specific care that, when grouped together, improve health care and guarantee patient safety ${ }^{(5)}$. This technology can be used by multidisciplinary teams, under the responsibility of a person or a team, unlike a checklist, which is fragmented and performed by several people. The selection of bundle elements must consider the cost, ease of implementation and adherence to the actions. Success depends on all measures being carried out together, without fragmenting the stages ${ }^{(5)}$.

As treatments for infection and immunization are still unknown, is in testing phase, strategies to improve practice are needed. It is believed that the development and validation of this bundle is an important action in practice, to promote the development of safer care, aimed at resolving and reducing maternal and child mortality, with an emphasis on the neonatal component.

Thus, the objective was to build and validate the contents of a bundle for the care of newborn children of mothers with suspected or confirmed diagnosis of COVID-19 in the delivery room and in the rooming-in.

\section{$\square$ METHODS}

This is a methodological research, developed in the year 2020, in three stages: survey of scientific production, construction of the instrument with guidelines for the care and validation of the content performed by judges, guided by the framework of quality improvement studies Standards for Quality Improvement Reporting Excellence (SQUIRE) from the network Enhancing the QUAlity and Transparency Of health Research (EQUATOR) ${ }^{(6)}$

The content validation allows to evaluate the clarity, the ease of reading, the understanding and the measurement of the intended items, proving the phenomenon of interest and the dimension of each item within what is intended to be investigated ${ }^{(7)}$. The theory of the elaboration of measurement instruments, involves the composition of three stages: theoretical (elaboration of items and content validity), empirical (pre-test and pilot test) and analytical (statistical analysis $)^{(7)}$. The theoretical and analytical stages of content validation will be presented.

To prepare the instrument items, an advanced search was performed in the Medical Literature Analysis and Retrieval System Online database (MEDLINE) using the search engine US National Library of Medicine National Institutes of Health (PubMed), in Latin American Literature and Caribbean in Health Sciences (Literatura Latino-Americana e do Caribe em Ciências da Saúde - LILACS) through the Virtual Health Library (Biblioteca Virtual em Saúde - BVS) and the Cochrane Library. Additionally, a manual search of references was performed with the articles collected. Primary and secondary studies published in Portuguese, English and Spanish were included, with no time frame 
and articles in other languages, expert opinion and letter to editor were excluded. The following question guided this survey: What are the essential care measures for the care of newborn children of mothers with suspected or confirmed diagnosis of COVID-19?

The searches were performed using controlled keywords from the Medical Subject Headings (MeSH) "Coronavirus Infections", "Nursing" and "Infant, Newborn" and, through the Health Sciences Descriptors (DeCS) "Coronavirus Infections", "Nursing" and "Newborn". The survey was carried out on September 21, 2020 and the results obtained were independently reviewed by two researchers.

The instrument for validation was built using the Hyper Text Markup Language standard (HTML) in Google Forms ${ }^{\oplus}$ to be completed via web in two parts. Part I consisted by the professional identification of the judges: institution where they work; professional qualification; titling and work sector. Part II consisted of the care to compose the bundle evaluated based on the Likert-type scale for the weightings: I totally disagree; partially disagree; I agree; partially agree and totally agree. At the end, the judges could give an opinion on the degree of importance and make suggestions for changes in a blank field.

The participating judges were nurses selected in a non-probabilistic manner according to the inclusion criteria: master's degree in Nursing (four points); master's degree in Nursing with a dissertation in the area of interest of the study (one point); doctoral thesis in the study area (two points); clinical practice of at least one year in the area of interest (one point); certificate of clinical practice (specialization) in the area of interest of the study (two points); relevant publication for the area of interest in a reference journal (two points). To be selected as a judge, the nurse must obtain a minimum of five points and have a master's degree(8).

Recruitment was performed by searching for researchers in obstetric and neonatal nursing in scientific publications and checking the criteria described in the Lattes Curriculum. All were doctors in nursing, six professors from federal universities and one worked in a teaching hospital.

The contact was made via email for the presentation of the study, Informed Consent Form (ICF) and link to the Google form. Upon the consent to participate and the selection of a specific item, the access to the instrument was allowed and, if he/she did not accept to participate, the process was closed. 25 nurses were contacted, seven of whom accepted, returned the instrument filled and participated in the three evaluation rounds. The adopted framework recommends a minimum of six judges ${ }^{(7)}$.
The data were imported from Google Forms ${ }^{\circledR}$ into a database in Excel $^{\oplus}$ format, for processing and analysis. The agreement among the judges was analyzed from the Content Validity Index (CVI) and items that obtained above $80 \%$ agreement were considered valid ${ }^{(9)}$. To calculate the $\mathrm{CVI}$, the number of responses was considered to agree, partially agree or totally agree divided by the total number of responses. To realize the adjustments suggested in the first round, the instrument was submitted to three rounds of evaluation.

The study was approved by the Research Ethics Committee of the Clinical Hospital of the Universidade Federal do Triângulo Mineiro (UFTM) upon submission to Plataforma Brasil and followed the recommendations of Resolution No. 466/12 of the National Health Council of Brazil through the Consubstantiated Statement No. 4.067.977, of 06/03/2020, and Certificate of Presentation for Ethical Appreciation (CAAE) No. 31316720.0.0000.5154.

\section{RESULTS}

The literature search identified 13 studies and notes from official agencies with relevant data on Nursing care with NB, child of mother with suspected or confirmed diagnosis of COVID-19 for the construction of the instrument to be validated by the judges (Figure 1).

Chart 1 presents the characteristics of the selected articles and the recommended care.

The initial instrument built for validation contained seven items about the care of newborns children of mothers with suspected or confirmed diagnosis of COVID-19 extracted from the survey carried out (Table 1).

In the first analysis, items 1,2,4,5, 6 and 7 present CVI above $80 \%$, with suggestions in items 2 and 5 . In item 2, the use of surgical or superior mask, face shield and overshoes and remove the repeated item: procedure gloves. In item 5, it was the skin-to-skin contact with the use of a mask in the delivery room, as it is a care suggested in studies identified in the bibliographic survey, the same being included, together with the previous item, to not perform, so that they could assess more clearly. Item 3 presented CVI below $80 \%$ with suggestions, being modified to "use N95 and PFF2 masks without a filter in procedures that generate aerosol". The items were referred for a new assessment (Table 2).

The second round allowed evaluating the modifications and the inclusion of items in the bundle. In this analysis, items $1,2,3,7$ and 8 presented CVI above $80 \%$, with few considerations. In item 7, it was suggested to reinforce the strictness of 

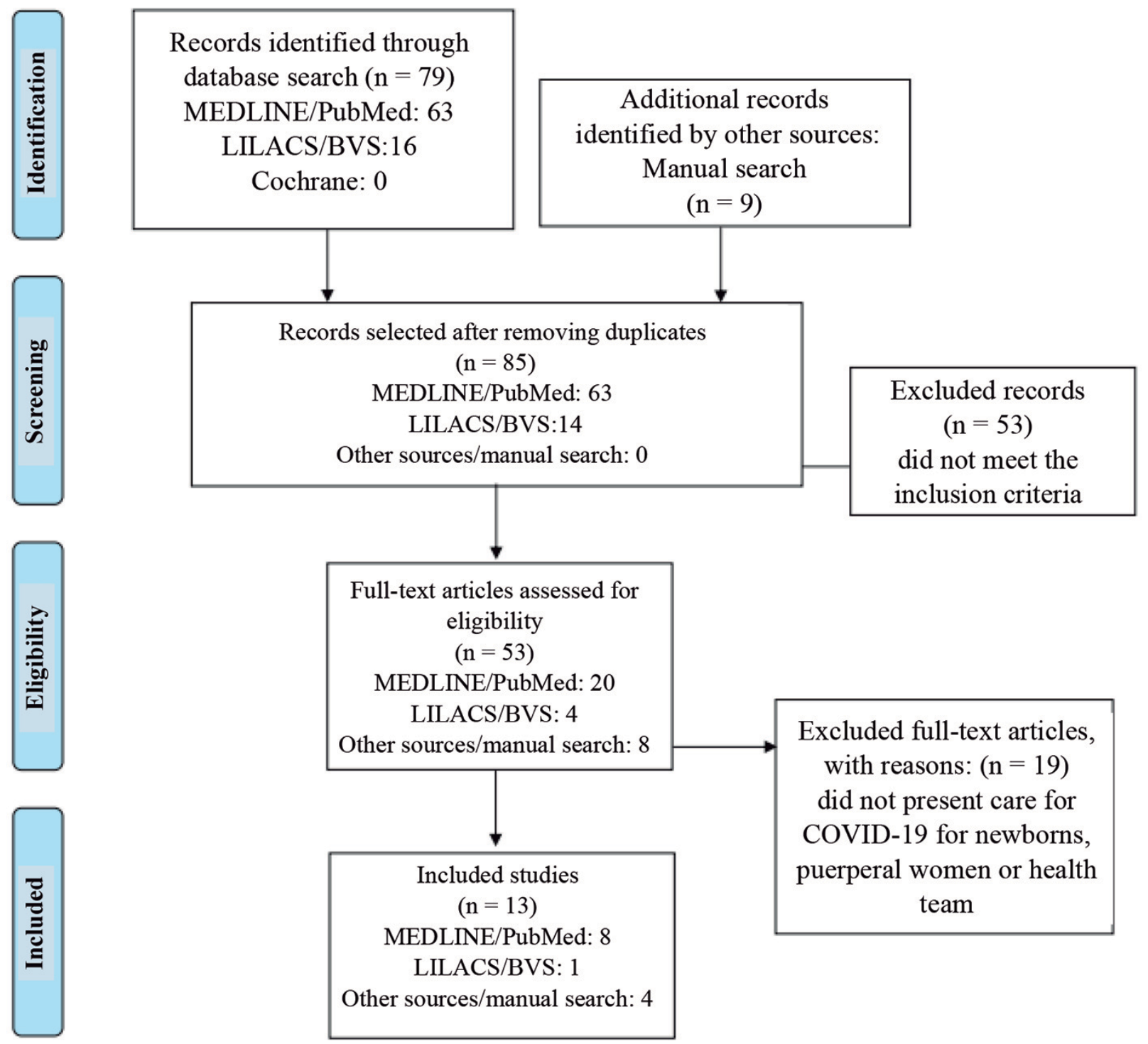

Full-text articles assessed for eligibility

$(\mathrm{n}=53)$

MEDLINE/PubMed: 20

LILACS/BVS: 4

Other sources/manual search: 8

Figure 1 - Flowchart of the selection of studies identified in the Preferred Reporting Items for Systematic Reviews and Meta-Analyses (PRISMA) recommendations

Source: Research data, 2020.

the use of personal protective equipment, changing it to "in the rooming-in care, perform breastfeeding maintenance and skin-to-skin contact with strict use of preventive measures (hand hygiene, distance of one meter between beds, use of surgical mask and respiratory etiquette) of asymptomatic and symptomatic mothers".

In item 8, it was suggested the inclusion of the companion in the guidance on preventive measures, reinforcing them: "guiding the mother and companions regarding preventive measures (hand hygiene, wearing a surgical mask and respiratory etiquette) in the delivery room and rooming-in". Items 4, 5 and 6 presented CVI below $80 \%$ and above $60 \%$. As they are essential items for care, they were reviewed in the literature, modified, and sent to a third evaluation.

In the third round, all items presented CVI above $80 \%$. The union of items 2 and 3 was proposed, as they deal with the use of personal protective equipment, modifying them to "Use of personal protective equipment: disposable and waterproof long-sleeved apron, surgical or superior mask, procedure gloves, glasses protection, face protector, hat and overshoes. Use mask N95 or PFF2 without filter in procedures that generate aerosol", resulting in the final version of the bundle with six items with a global CVI of 0.96. (Table 3). 
Author/Year

Title/Journal
Recommended care

\section{MEDLINE/PubMed}

\begin{tabular}{|c|c|c|}
\hline Amatya et al, 2020(10) & $\begin{array}{l}\text { Management of newborns } \\
\text { exposed to mothers with } \\
\text { confirmed or suspected } \\
\text { COVID-19. J Perinatol. }\end{array}$ & $\begin{array}{l}\text { Careful use of personal protective equipment by the } \\
\text { health team, long-sleeve disposable apron, surgical mask, } \\
\text { face shield, gloves and N95 for procedures that generate } \\
\text { aerosols; use of surgical mask for mothers with confirmed } \\
\text { diagnosis; timely clamping of the umbilical cord with an } \\
\text { obstetrician holding the NB for mothers with suspected } \\
\text { or confirmed diagnosis; separating mother and newborn } \\
\text { should be a decision together with the family; use } \\
\text { of personal protective equipment for companions; } \\
\text { promote breastfeeding. }\end{array}$ \\
\hline $\begin{array}{l}\text { Davanzo et } \\
\text { al, } 2020^{(11)}\end{array}$ & $\begin{array}{l}\text { Breastfeeding and coronavirus } \\
\text { disease-2019: Ad interim } \\
\text { indications of the Italian Society } \\
\text { of Neonatology endorsed by } \\
\text { the Union of European Neonatal } \\
\text { \& Perinatal Societies. Maternal \& } \\
\text { Child Nutrition. }\end{array}$ & $\begin{array}{l}\text { Promote breastfeeding; encourage the use of maternal } \\
\text { bed in situations that the mother cannot breastfeed } \\
\text { and interaction between the mother-baby binomial; } \\
\text { separating mother and newborn should be an individual } \\
\text { decision; keep the newborn's crib at a distance of } 2 \\
\text { meters from the mother's head; guide the use of surgical } \\
\text { masks during breastfeeding and correct hand hygiene; } \\
\text { judicious use of personal protective equipment by the } \\
\text { health team and companions. }\end{array}$ \\
\hline $\begin{array}{l}\text { Fernández-Carrasco } \\
\text { et al, 2020 }\end{array}$ & $\begin{array}{l}\text { Coronavirus Covid-19 } \\
\text { infection and breastfeeding: } \\
\text { an exploratory review. Rev Esp } \\
\text { Salud Publica. }\end{array}$ & $\begin{array}{l}\text { Promote breastfeeding; encourage the use of breast } \\
\text { milk in situations that the mother cannot breastfeed; } \\
\text { guide the use of surgical masks during breastfeeding and } \\
\text { correct hand hygiene. }\end{array}$ \\
\hline Freitas et al, $2020^{(13)}$. & $\begin{array}{l}\text { Prevention and control } \\
\text { measures for neonatal COVID-19 } \\
\text { infection: scope review. Rev } \\
\text { Bras Enferm. }\end{array}$ & $\begin{array}{l}\text { Judicious use of personal protective equipment by the } \\
\text { health team, cap, goggles or face shield, long sleeve } \\
\text { disposable apron, gloves, N95 masks; in the delivery } \\
\text { room, the mother must wear a surgical mask, suspend } \\
\text { skin-to-skin contact and perform timely clamping } \\
\text { of the umbilical cord, postpone breastfeeding until } \\
\text { the newborn receives hygiene care and preventive } \\
\text { measures for contamination by SARS-CoV2; encourage } \\
\text { breastfeeding or the use of breast milk in situations } \\
\text { that the mother cannot breastfeed, with the use of } \\
\text { masks during breastfeeding and correct hand hygiene } \\
\text { and utensils necessary for extracting milk. Maintain a } \\
\text { minimum distance of one meter between the mother's } \\
\text { bed and the newborn's crib; guide companions on the } \\
\text { use of personal protective equipment and hand hygiene } \\
\text { before and after newborn care. }\end{array}$ \\
\hline Genoni et al, 2020(14). & $\begin{array}{l}\text { Management and Nutrition } \\
\text { of Neonates during the } \\
\text { COVID-19 Pandemic: A Review } \\
\text { of the Existing Guidelines } \\
\text { and Recommendations. Am } \\
\text { J Perinatol. }\end{array}$ & $\begin{array}{l}\text { Promote breastfeeding; encourage the use of breast milk } \\
\text { in situations that the mother cannot breastfeed; guide } \\
\text { the use of surgical masks during feedings; guide correct } \\
\text { hand hygiene; separating mother and newborn should } \\
\text { be an individualized decision. Chinese recommendations } \\
\text { guide to separate the binomial for } 14 \text { days. }\end{array}$ \\
\hline
\end{tabular}

Chart 1 - Characterization of the articles identified in the search 


\begin{tabular}{|c|c|c|}
\hline Author/Year & Title/Journal & Recommended care \\
\hline $\begin{array}{l}\text { Marín Gabriel et } \\
\text { al, } 2020^{(15)} \text {. }\end{array}$ & $\begin{array}{l}\text { Negative Transmission } \\
\text { of SARS-CoV-2 to Hand- } \\
\text { Expressed Colostrum from } \\
\text { SARS-CoV-2-Positive Mothers. } \\
\text { Breastfeed Med. }\end{array}$ & Promote and encourage breastfeeding. \\
\hline $\begin{array}{l}\text { Muhidin et } \\
\text { al, 2020 }\end{array}$ & $\begin{array}{l}\text { Analysis of Maternal Coronavirus } \\
\text { Infections and Neonates Born } \\
\text { to Mothers with 2019-nCoV; a } \\
\text { Systematic Review. Arch Acad } \\
\text { Emerg Med. }\end{array}$ & $\begin{array}{l}\text { Judicious use of personal protective equipment by } \\
\text { the health team, hat, protective glasses or face shield, } \\
\text { disposable long sleeve apron, gloves, N95 masks. }\end{array}$ \\
\hline De Rose et al, $2020^{(4)}$. & $\begin{array}{l}\text { Novel Coronavirus disease } \\
\text { (COVID-19) in newborns and } \\
\text { infants: what we know so far. Ital } \\
\text { J Pediatr. }\end{array}$ & $\begin{array}{l}\text { Judicious use of personal protective equipment by the } \\
\text { health team, cap, goggles or face shield, long sleeve } \\
\text { disposable apron, gloves, N95 masks; keep the newborn's } \\
\text { crib at a distance of } 2 \text { m from the mother's head; guide } \\
\text { the use of surgical masks and the hygiene of mothers in } \\
\text { the rooming-in care for mothers and companions. }\end{array}$ \\
\hline \multicolumn{3}{|l|}{ LILACS/BVS } \\
\hline $\begin{array}{l}\text { Mascarenhas, et } \\
\text { al, } 2020^{(17)} \text {. }\end{array}$ & $\begin{array}{l}\text { Care recommendations for } \\
\text { parturient, puerperal and } \\
\text { newborn during the COVID-19 } \\
\text { pandemic: scope review. Rev } \\
\text { Latino-Am Enfermagem. }\end{array}$ & $\begin{array}{l}\text { Judicious use of personal protective equipment by the } \\
\text { health team, cap, goggles or face shield, long sleeve } \\
\text { disposable apron, gloves, N95 masks; during cesarean } \\
\text { section, pregnant women who are not under general } \\
\text { anesthesia should wear surgical masks throughout } \\
\text { the delivery; promote breastfeeding; encourage the } \\
\text { use of breast milk in situations that the mother cannot } \\
\text { breastfeed; guide the use of surgical masks during } \\
\text { feedings; guide correct hand hygiene. }\end{array}$ \\
\hline \multicolumn{3}{|c|}{ Other sources/manual Search } \\
\hline $\begin{array}{l}\text { Dotters-Katz et } \\
\text { al, 2020(18) }\end{array}$ & $\begin{array}{l}\text { Considerations for Obstetric } \\
\text { Care during the COVID-19 } \\
\text { Pandemic. Am J Perinatol. }\end{array}$ & $\begin{array}{l}\text { Judicious use of personal protective equipment by the } \\
\text { health team, including face shield; keep the newborn's } \\
\text { crib at a distance of } 2 \mathrm{~m} \text { from the mother's head; } \\
\text { promote breastfeeding; encourage the use of breast milk } \\
\text { in situations that the mother cannot breastfeed, guide } \\
\text { the use of surgical masks during breastfeeding; guide } \\
\text { the correct hand hygiene and utensils necessary for } \\
\text { extracting milk, if applicable. }\end{array}$ \\
\hline Liu et al, $2020^{(19)}$. & $\begin{array}{l}\text { Clinical characteristics of } 19 \\
\text { neonates born to mothers with } \\
\text { COVID-19. Front Med. }\end{array}$ & Separate infected mothers from newborns. \\
\hline
\end{tabular}

Chart 1 - Cont. 


\begin{tabular}{|c|c|c|}
\hline Author/Year & Title/Journal & Recommended care \\
\hline $\begin{array}{l}\text { Ministério da } \\
\text { Saúde, } 2020^{(3)} \text {. }\end{array}$ & $\begin{array}{l}\text { Technical note } n^{0} 14 / 2020 \text {. } \\
\text { Attention to the health of } \\
\text { the newborn in the context } \\
\text { of infection with the new } \\
\text { coronavirus (SarsCoV-2). Ministry } \\
\text { of Health. }\end{array}$ & $\begin{array}{l}\text { For asymptomatic parturient who do not have home } \\
\text { contact with a person with flu syndrome or respiratory } \\
\text { infection proven by Sars-CoV-2: maintaining the clamping } \\
\text { of the umbilical cord at birth in time, skin-to-skin contact } \\
\text { and breastfeeding in the first hour of life. } \\
\text { For symptomatic parturient or those who have home } \\
\text { contact with a person with influenza syndrome or } \\
\text { respiratory infection proven by SARS-CoV-2: keep the } \\
\text { routine of clamping the umbilical cord timely. Dry } \\
\text { the newborn with the cord intact, with no need for a } \\
\text { bath immediately after birth. Skin-to-skin contact and } \\
\text { breastfeeding may occur after the parturient's hygiene } \\
\text { care, including bed bathing, changing of mask, cap, } \\
\text { nightgown and sheets. } \\
\text { For mothers with flu-like symptoms, keep at least } 1 \\
\text { meter and preferably } 2 \text { meters between the mother's } \\
\text { bed and the newborn's crib, use of a mask by the } \\
\text { symptomatic mother during contact for care and during } \\
\text { all breastfeeding and proper hand hygiene before and } \\
\text { after contact with the child. } \\
\text { Promote breastfeeding with recommended precautions, } \\
\text { such as wearing masks and hand hygiene. }\end{array}$ \\
\hline $\begin{array}{l}\text { World Health } \\
\text { Organization. 2020(2). }\end{array}$ & $\begin{array}{l}\text { Clinical Management of Severe } \\
\text { Acute Respiratory Infection } \\
\text { (SARI) when COVID19 Disease } \\
\text { is Suspected. Geneva: World } \\
\text { Health Organization. }\end{array}$ & $\begin{array}{l}\text { Mothers with suspected or confirmed COVID-19 should } \\
\text { be encouraged to start and continue to breastfeed. }\end{array}$ \\
\hline
\end{tabular}

Chart 1 - Cont.

Source: Research data, 2020.

Table 1 - First round of bundle content validation for the care of newborn children of mothers with suspected or confirmed diagnosis of COVID-19, Uberaba, MG, Brazil, 2020

\section{Care}

1. Hand hygiene with water and liquid soap or alcoholic preparation (70\%).

2. Use of personal protective equipment: disposable and waterproof long-sleeved apron, procedure

gloves, procedure gloves and hat.

3. Use mask N95 or PFF2.

4. Do not position the newborn in the mother's abdomen or chest during cord clamping.

5. Do not make skin to skin contact in the delivery room.

6. In the rooming-in care carry out maintenance of breastfeeding.

7. Guide the breastfeeding mother about preventive measures and the use of masks. 
Table 2 - Second round of bundle content validation for the care of newborn children to stable mothers with suspected or confirmed diagnosis of COVID-19, Uberaba, MG, Brazil, 2020

2. Use of personal protective equipment: disposable and waterproof long-sleeved apron, surgical mask or superior, procedure gloves, goggles, face shield, hat and overshoes. Use N95 or PFF2 mask without filter in procedures that generate aerosol.

3. Use N95 or PFF2 mask without filter in procedures that generate aerosol.

4. Do not position the newborn in the abdomen or maternal thorax while clamping the umbilical cord.

5. Do not make skin to skin contact in the delivery room.

6. Make skin-to-skin contact in the delivery room using a mask.

7. In the rooming-in care, carry out the maintenance of breastfeeding.

8. Guide the breastfeeding mother about preventive measures and the use of masks.

Source: Research data, 2020.

Table 3 - Third round of content validation and final version of the bundle to care for newborn children to stable mothers with suspected or confirmed diagnosis of COVID-19, Uberaba, MG, Brazil, 2020

1. Hand hygiene with water and liquid soap or alcoholic gel preparation (70\%).

2. Use of personal protective equipment: disposable and waterproof long-sleeved apron, surgical mask or superior, procedure gloves, goggles, face shield, hat and overshoes. Use N95 or PFF2 mask without filter in procedures that generate aerosol.

3. Make timely clamping of the umbilical cord with a newborn in the mother's abdomen, skin-toskin contact and breastfeeding in the delivery room of asymptomatic mothers with rigorous use of a surgical mask.

4. Make skin-to-skin contact and breastfeeding in the delivery room of symptomatic mothers after ensuring the hygiene care of the parturient, including bathing, changing the mask, cap, nightgown and sheets.

5. In the rooming-in care, carry out maintenance of breastfeeding and skin-to-skin contact with strict use of preventive measures (hand hygiene, one meter distance between beds, use of surgical mask and respiratory etiquette) of asymptomatic and symptomatic mothers.

6. Guide the mother and companions regarding preventive measures (hand hygiene, use of surgical mask and respiratory etiquette) in the delivery room and in the rooming-in care.

Source: Research data, 2020

\section{DISCUSSION}

There are several recommendations in the literature about assistance for childbirth and delivery in different countries affected by the pandemic, but there is no consensus for the conduct adopted in practice, and each reality can adopt and prioritize local or international standards ${ }^{(13,17)}$. A review study demonstrates that the research performed to date in 
the maternal and child area is incipient, with few primary studies, and most were carried out in China, where the first cases were reported ${ }^{(13)}$.

The use of bundles has been recommended to contribute to excellence in care, it needs to go through the validation process to assess its quality, as well as the robustness of the results ${ }^{(6)}$. The purpose of this study was to elaborate and validate the content of a bundle with the main nursing care in the care of newborns, children of mothers with suspected or confirmed diagnosis of COVID-19 in the delivery room and in the rooming-in care, care based on the best available evidence and national and international recommendations from official bodies, to contribute to the standardization of safe and quality care to this audience.

Due to the risk of contamination by droplets, aerosols and contact during labor, birth and postpartum, the team must be aware of the diagnosis to properly prepare and follow biosafety recommendations ${ }^{(17)}$.

Thus, the first care listed to compose the bundle was "Hand hygiene with water and liquid soap or alcoholic gel preparation (70\%)". One of the most effective and low-cost preventive measures for the prevention of microorganisms is hand hygiene. It is recommended to be performed with water and soap, preferably liquid or foam, when the hands are visibly dirty, before and after touching the patient, when performing procedures, with risk of exposure to body fluids and contact with nearby areas. to the patient. If the hands are not visibly dirty, hygiene can be performed with alcohol gel at a concentration of $70 \%$. When done properly, simple hand hygiene is able to reduce the occurrence of preventable infections, such as COVID-19 $9^{(20-21)}$. SARS-CoV-2 has an outer layer of lipids that is easily degraded when in contact with soap ${ }^{(22)}$. However, it is noted, both by health professionals and the population, that there are barriers that hinder adherence to this technique ${ }^{(21)}$.

The second was related to the use of personal protective equipment: "Use of personal protective equipment: disposable and waterproof long-sleeved apron, surgical or superior mask, procedure gloves, goggles, face shield, hat and overshoes. Use N95 or PFF2 mask without filter in procedures that generate aerosol". The use of personal protective equipment for health professionals during visits is essential to avoid contamination and the spread of infection. In suspected or confirmed cases with COVID-19, it is recommended to use a disposable and waterproof long-sleeved apron, procedure gloves, goggles, face shield, surgical mask or superior, cap and overshoes. In caesarean sections, the apron must be placed over specific private clothing. For aerosol generating procedures, N95 or PFF2 masks without a filter must be used ${ }^{(20-21)}$.
Items 3 and 4 concern to skin-to-skin contact and breastfeeding in the delivery room for symptomatic and asymptomatic mothers. From the studies identified, one carried out in France identified a confirmed case of vertical transmission in all specimens described in a late infected pregnant woman ${ }^{(6)}$. The others did not have confirmation or did not perform on all specimens ${ }^{(19,23-24)}$. To determine vertical transmission, diagnostic confirmation is required in all specimens of the newborn and the mother, determining the route of transmission. It should be performed the Polymerase Chain Reaction (RT-PCR) of the newborn, the mother, the amniotic fluid, the vaginal secretion during vaginal delivery, the umbilical cord blood, breast milk and the anatomopathological examination of the placenta ${ }^{(25)}$.

Studies have recommended the early clamping of the umbilical cord and the separation of the mother and child binomial after birth for 14 days, in order to avoid contagion ${ }^{(19,23)}$. However, there is no strong evidence that the separation of the binomial prevents infection by SARS-CoV-2, since it is not possible, through this measure, to guarantee non-exposure after hospital discharge. It is noteworthy that the interruption of skin-to-skin contact can disturb the newborn's physiology and adaptation and hinder the early initiation of breastfeeding ${ }^{(26)}$.

The WHO recommends timely clamping of the umbilical cord, that is, for at least one to three minutes, to guarantee the benefits to the newborn. Based on the fact that the risk of COVID-19 infection in NBs is low and the disease is usually mild or asymptomatic, it is advisable not to separate the binomial, stimulate skin-to-skin contact, the kangaroo position and ensure the beginning of breastfeeding in the first hour of life with the appropriate use of personal protective equipment. Considering that the losses in not performing these procedures are greater, such as stress, difficulties in maintaining temperature and glycemic control, delay in the initiation of breastfeeding and risk of failure to breastfeed and a greater occurrence of colonization and infection by other pathogens ${ }^{(2)}$.

A note from the Ministry of Health $(\mathrm{MH})$ recommends that, in cases of asymptomatic and symptomatic women who are clinically stable, the routine of timely clamping of the umbilical cord should be maintained, with no need for a bath immediately after birth. As for skin-to-skin contact and breastfeeding, the note states that they should be encouraged for asymptomatic mothers and that they have had no home contact with infected people. If they show symptoms or have had contact with infected people, it is recommended to initiate skin-to-skin contact and breastfeeding after ensuring the hygiene care of parturient, including bathing, changing the mask, cap, nightgown and bed sheets ${ }^{(4)}$. 
Although there are these recommendations from WHO and $\mathrm{MH}$, there are contradictions in care practices in the delivery room. The evaluation of the judges in this study considered it appropriate to follow the recommendations proposed by the $\mathrm{MH}$ made available so far, using skin-to-skin contact, timely clamping the umbilical cord with newborns in the abdomen and breastfeeding in asymptomatic parturient and, for symptomatic women, carry out after ensuring hygiene care.

Item five encourages breastfeeding and skin-to-skin contact in the rooming-in care: "In the rooming-in care, carry out maintenance of breastfeeding and skin-to-skin contact with strict use of preventive measures (hand hygiene, one meter distance between the beds, use of surgical mask and respiratory etiquette) of asymptomatic and symptomatic mothers". For puerperal women with suspected or confirmed diagnosis of COVID-19, WHO strongly recommends that the mother and the newborn remain together and that skin-toskin contact is practiced for as long as they deem necessary ${ }^{(2)}$.

O $n$ the other hand the technical note of the Brazilian Ministry of Health recommends private isolation and maintaining a distance of two meters between the maternal bed and the newborn, between feeding intervals. Mothers should be instructed on proper hand hygiene, especially before touching the baby and its belongings. After breastfeeding, ask someone else to take care of the newborn. If this is not possible, the mother should be instructed to use procedure gloves ${ }^{(4)}$. The Center for Disease Control (CDC) considers it important to separate the binomial until the mother is considered out of contagion. During separation, it advises the mother to extract the milk, using personal protective equipment, to be offered to the newborn ${ }^{(27)}$.

With divergent recommendations, in this study, the judges considered important to encourage the maintenance of breastfeeding and skin-to-skin contact with the rigorous use of preventive measures. The puerperal woman should be instructed to use the surgical mask at all times, changing it every two hours, following the respiratory etiquette and cleaning the hands before and after touching the newborn and their belongings.

Finally, item six addresses "Orienting the mother and companions regarding preventive measures (hand hygiene, wearing a surgical mask and respiratory etiquette) in the delivery room and rooming-in". The right to a woman's free choice of companion is provided by law and must be maintained following the guidelines of strict use of masks, preventive measures and respiratory etiquette ${ }^{(4)}$.

The guidelines listed to compose the bundle were based on current scientific evidence. In view of the modifiable scenario of the pandemic and the realization of new studies on the subject, this information may be changed, at an opportune moment, if necessary.

Since 2019, Brazil has joined the Nursing Now campaign, which aims to empower nurses and improve global health by strengthening Nursing, which occupies a global leadership role in health. Thus, this study sought to demonstrate that nurses must be able to cross the boundary of knowledge and act as leaders to plan and coordinate safety and quality measures through good practices based on scientific evidence, making them protagonists of care and prevention and health promotion measures.

\section{CONCLUSION}

This study allowed the construction and validation of the contents of a bundle, together with the judges, for the attendance of NBs children of mothers with suspected or confirmed diagnosis of COVID-19 in the delivery room and in the rooming-in care. The listed care was related to hand hygiene, the appropriate use of personal protective equipment by professionals, the parturient and the companion, care during the clamping of the umbilical cord, breastfeeding and skin-to-skin contact in the delivery room and in the rooming-in care.

Care for pregnant women, puerperal women and newborns must be rigorous and continuous, regardless of the clinical history, as they are more vulnerable groups to have complications in the presence of COVID-19. The adoption of this bundle may contribute to the quality of Nursing care and conduct in relation to the care of these newborns as a complementary technology to care, given the current impact of the pandemic and the scarcity of precise and formal recommendations for coping with this disease.

It can be considered as limitations of this study differences in the available recommendations, scarce studies on the subject and insufficient evidence to confirm or rule out mother-to-child transmission. Further research is recommended to test the usability and effectiveness of the bundle built.

\section{REFERENCES}

1. Mimouni F, Lakshminrusimha S, Pearlman AS, Raju T, Gallagher PG, Mendlovic J. Perinatal aspects on the covid-19 pandemic: a practical resource for perinatalneonatal specialists. J Perinatol. 2020;40:820-6. doi: https://doi.org/10.1038/ s41372-020-0665-6

2. World Health Organization (CH). Clinical management of Severe Acute Respiratory Infection (SARI) when COVID19 disease is suspected: interim guidance 13 March 2020. Geneva: WH0; 2020 [cited 2020 Nov 14]. Available from: https://apps.who.int/iris/bitstream/handle/10665/331446/WHO-2019nCoV-clinical-2020.4-eng.pdf 
3. Ministério da Saúde (BR). Secretaria de Atenção Primária à Saúde. Nota técnica n014/2020-COCAM/CGCIVI/DAPES/SAPS/MS. Atenção à saúde do recémnascido no contexto da infecção pelo novo coronavírus (SarsCoV-2). Brasília, DF; 2020 [cited 2020 0ct 30]. Available from: https://rblh.fiocruz.br/sites/rblh. fiocruz.br/files/usuario/116/nova_nt_14_2020.pdf

4. De Rose DU, Piersigilli F, Ronchetti MP, Santisi A, Bersani I, Dotta A, et al. Novel Coronavirus disease (COVID-19) in newborns and infants: what we know so far. Ital J Pediatr. 2020;46:56. doi: https://doi.org/10.1186/ s13052-020-0820-x

5. Silva $A G$, Oliveira $A C$. Impact of the bundles implementation on the reduction of bloodstream infections: an integrative review. Texto Contexto Enferm. 2018;27(1):e3540016. doi: https://doi. org/10.1590/0104-07072018003540016

6. Ogrinc G, Davies L, Goodman D, Batalden P, Davidoff F, Stevens D. SQUIRE 2.0 (Standards for QUality Improvement Reporting Excellence): revised publication guidelines from a detailed consensus process. BMJ Qual Saf. 2016;25:986-92. doi: https://doi.org/10.1136/bmjqs-2015-004411

7. Pasquali L. Instrumentação psicológica: fundamentos e práticas. Porto Alegre: Artmed; 2010.

8. Fehring RJ. Methods to validate nursing diagnoses. Heart Lung. 1987 [cited 2020 Sep 14];16(6):625-9. Available from: https://www.researchgate.net/ publication/40505773_Methods_to_Validate_Nursing_Diagnoses

9. Polit DF, Beck CT. Fundamentos de pesquisa em enfermagem: avaliação de evidências para a prática de enfermagem. 9. ed. Porto Alegre: Artmed; 2019.

10. Amatya S, Corr TE, Gandhi CK, Glass KM, Kresch MJ, Mujsce DJ, et al. Management of newborns exposed to mothers with confirmed or suspected CovID-19. J Perinatol. 2020;40(7):987-96. doi: https://doi.org/10.1038/ s41372-020-0695-0

11. Davanzo R, Moro G, Sandri F, Agosti M, Moretti C, Mosca F. Breastfeeding and coronavirus disease-2019: ad interim indications of the Italian Society of Neonatology endorsed by the Union of European Neonatal \& Perinatal Societies. Matern Child Nutr. 2020;16(3):e13010. doi: https://doi.org/10.1111/ mcn. 13010

12. Fernández-Carrasco FJ, Vázquez-Lara JM, González-Mey U, Gómez-Salgado J, Parrón-Carreño T, Rodríguez-Díaz L. [Coronavirus Covid-19 infection and breastfeeding: na exploratory review]. Rev Esp Salud Publica. 2020 [cited 2020 Sep 14];27(94):e202005055. Spanish. Available from: https://www.mscbs. gob.es/biblioPublic/publicaciones/recursos_propios/resp/revista_cdrom/ VOL94/REVISIONES/RS94C_202005055.pdf

13. Freitas BHBM, Alves MDSM, Gaíva MAM. Prevention and control measures for neonatal COVID-19 infection: a scoping review. Rev Bras Enferm. 2020;73(Suppl 2):e20200467. doi: https://doi.org/10.1590/0034-7167-2020-0467

14. Genoni G, Conio A, Binotti M, Manzoni P, Castagno M, Rabbone I, et al. Management and nutrition of neonates during the COVID-19 pandemic: a review of the existing guidelines and recommendations. Am J Perinatol. 2020;37(S 02):S46-S53. doi: https://doi.org/10.1055/s-0040-1714675
15. Marín Gabriel MA, Malalana Martínez AM, Marín Martínez ME, Anel Pedroche J. Negative transmission of SARS-CoV-2 to hand-expressed colostrum from SARSCoV-2-positive mothers. Breastfeed Med. 2020 Aug;15(8):492-4. doi: https:// doi.org/10.1089/bfm.2020.0183

16. Muhidin S, Behboodi Moghadam Z, Vizheh M. Analysis of maternal coronavirus infections and neonates born to mothers with 2019-nCoV; a systematic review. Arch Acad Emerg Med. 2020 [cited 2020 Sep 14];8(1):e49. Available from: https://www.ncbi.nlm.nih.gov/pmc/articles/PMC7211430/

17. Mascarenhas VHA, Caroci-Becker A, Venâncio KCMP, Baraldi NG, Durkin $A C$, Riesco MLG. Care recommendations for parturient and postpartum women and newborns during the COVID-19 pandemic: a scoping review. Rev Latino-Am Enfermagem. 2020;28:e3359. doi: https://doi. org/10.1590/1518-8345.4596.3359

18. Dotters-Katz SK, Hughes BL. Considerations for obstetric care during the COVID-19 pandemic. Am J Perinatol. 2020;37(8):773-9. doi: https://doi. org/10.1055/s-0040-1710051

19. Liu W, Wang J, LiW, Zhou Z, Liu S, Rong Z. Clinical characteristics of 19 neonates born to mothers with COVID-19. Front Med. 2020;14(2):193-8. doi: https://doi. org/10.1007/s11684-020-0772-y

20. Zhang G, Pan H, Hu X, He S, Chen Y, Wei C, et al. The role of isolation rooms, facemasks and intensified hand hygiene in the prevention of nosocomial COVID-19 transmission in a pulmonary clinical setting. Infect Dis Poverty. 2020;9:104. doi: https://doi.org/10.1186/s40249-020-00725-z

21. Oliveira AC, Lucas TC, Iquiapaza RA. What has the Covid-19 pandemic taught us about adopting preventive measures? Texto Contexto Enferm. 2020;29:e20200106. doi: https://doi.org/10.1590/1980-265x-tce-2020-0106

22. Gupta MK, Lipner SR. Hand hygiene in preventing COVID-19 transmission [commentary]. Cutis. 2020 [cited 2020 Sep 24];105(5):233-4. Available from: https://mdedge-files-live.s3.us-east-2.amazonaws.com/files/s3fs-public/ Gupta\%202020\%20CT105005233.pdf

23. Wu Y-T, Liu J, Xu J-J, Chen Y-F, Yang W, Chen Y, et al. Neonatal outcome in 29 pregnant women with COVID-19: a retrospective study in Wuhan, China. PLOS Med. 2020;17(7):e1003195. doi: https://doi.org/10.1371/journal.pmed.1003195

24. Melo GC, Araújo KCGM. COVID-19 infection in pregnant women, preterm delivery, birth weight, and vertical transmission: a systematic review and meta-analysis. Cad Saúde Pública. 2020;36(7):e00087320. doi: https://doi. org/10.1590/0102-311×00087320

25. Vivanti AJ, Vauloup-Fellous C, Prevot S, Zupan V, Suffee C, Cao JD, et al. Transplacental transmission of SARS-CoV-2 infection. Nat Commun, 2020;11:3572. doi: https://doi.org/10.1038/s41467-020-17436-6

26. Stuebe A. Should infants be separated from mothers with COVID-19? first, do no harm. Breastfeed Med. 2020;15(5):351-2. doi: https://doi.org/10.1089/ bfm.2020.29153.ams

27. Centers for Disease Control and Prevention (US). Atlanta: CDC; C2020 [cited 2020 Sep 10]. Interim considerations for inpatient obstetric healthcare settings; [about 1 screen]. Available from: https://www.cdc.gov/coronavirus/2019ncov/hcp/inpatient-obstetric-healthcare-guidance.html 
Silva MPC, Rocha NHG, Teixeira CLSB, Ued FV, Ruiz MT, Contim D

\section{- Acknowledgments:}

To the participating judges for their contributions in validating the bundle's content.

\section{- Authorship contribution:}

Maria Paula Custódio Silva - Conceptualization, Data curation, Formal analysis, Investigation, Methodology, Resources, Software, Validation, Writing-original draft, Writing-review \& editing. Nylze Helena Guillarducci Rocha - Writing-original draft, Writing-review \& editing.

Cinthia Lorena Silva Barbosa Teixeira - Writing-review \& editing.

Flávia da Veiga Ued - Writing-review \& editing. Mariana Torreglosa Ruiz - Data curation, Formal analysis, Methodology, Writing-original draft, Writingreview \& editing.

Divanice Contim - Conceptualization, Data curation, Formal analysis, Investigation, Methodology, Project administration, Resources, Software, Supervision, Validation, Visualization, Writing-original draft, Writingreview \& editing.

\section{- Corresponding author:}

Maria Paula Custódio Silva

Email: maria_paulacs@hotmail.com

Associate editor:

Dagmar Elaine Kaiser

Editor-in-chief:

Maria da Graça Oliveira Crossetti 